\title{
Karyotypic diversity in seven Amazonian anurans in the genus Hypsiboas (family Hylidae)
}

Thais Lemos de Mattos ${ }^{1 *}$, Ana Carolina Coelho ${ }^{1}$, Carlos Henrique Schneider ${ }^{2}$, David Otávio Carmo Telles ${ }^{3}$, Marcelo Menin ${ }^{2}$ and Maria Claudia Gross ${ }^{2}$

\begin{abstract}
Background: Hypsiboas species have been divided into seven groups using morphological and genetic characters, but for most of the species, there is no cytogenetic information available. A cytogenetic analysis using conventional staining, C-banding, silver staining, and fluorescence in situ hybridization (FISH) with telomeric sequence probes were used to investigate the karyotype of seven Amazon species of the genus Hypsiboas belonging to the following intrageneric groups: $H$. punctatus ( $H$. cinerascens), H. semilineatus (H. boans, H. geographicus, and H. wavrini), and $H$. albopunctatus (H. lanciformis, H. multifasciatus, and H. raniceps). The aim was to differentiate between the karyotypes and use the chromosomal markers to distinguish between the Hypsiboas groups. The data were compared with a previous phylogenetic proposal for these anurans. In addition, $H$. lanciformis, H. boans, and H. wavrini are described here for the first time, and we characterize the diploid numbers for $H$. cinerascens, H. geographicus, H. multifasciatus, and $H$. raniceps.

Results: The diploid number for all of the species analyzed was 24, with the exception of Hypsiboas lanciformis, which had $2 n=22$ chromosomes. The constitutive heterochromatin distribution, nucleolar organizer region locations, and interstitial telomeric sites differed between the species. A hypothesis that the heterochromatic patterns are evolving is proposed, with the divergence of the groups probably involving events such as an increase in the heterochromatin in the species of the H. semilineatus group. The FISH conducted with the telomeric probes detected sites in the terminal regions of all of the chromosomes of all species. Interstitial telomeric sites were detected in three species belonging to the H. semilineatus group: H. boans, H. geographicus, and H. wavrini.

Conclusion: The results of this study reinforce the complexity previously observed within the genus Hypsiboas and in the different groups that compose this taxon. More studies are needed focusing on this group and covering larger sampling areas, especially in the Brazilian Amazon, to improve our understanding of this fascinating and complex group.
\end{abstract}

Keywords: Hypsiboas groups, Chromosomes, Heterochromatin, Nucleolar organizer region, Telomere

\section{Background}

Hylidae is considered the most diverse family among the anurans, with 936 described species [1], of which about 90 are found in the Brazilian Amazon [2]. Recent cytogenetic studies of species from this family have demonstrated intrapopulational variation, with polymorphisms of the nucleolar organizer regions (NORs) [3], different diploid numbers in the same nominal species

\footnotetext{
* Correspondence: tldmattos@gmail.com

${ }^{1}$ Instituto Nacional de Pesquisas da Amazônia, Programa de Pós-Graduação em Genética, Conservação e Biologia Evolutiva, Av. André Araújo, 2936, 69080-971 Manaus, AM, Brazil

Full list of author information is available at the end of the article
}

$[4,5]$ and intra-generic variations such as the localization of the NORs among species [6].

Based on a compilation of cytogenetic data for the hylids, the majority of the species had a diploid number of 26 [7], although some genus such as the Hypsiboas spp. showed reductions, with the majority having $2 \mathrm{n}=24$ chromosomes [8-12]. Despite the conserved constant diploid number found in Hypsiboas spp., the karyotypic organization of the species cannot be considered conserved (Table 1) [4-30].

The species of the Hypsiboas genus have been separated into seven large species groups: $H$. albopunctatus; $H$. benitezi; $H$. faber; $H$. pellucens; $H$. pulchellus; $H$. 
Table 1 Review of cytogenetic data available in the literature for Hypsiboas species

\begin{tabular}{|c|c|c|c|c|c|c|c|c|}
\hline GR & Specie & Locality & $2 n$ & $\mathrm{CF}$ & NF & C-banding & NOR (pair) & Reference \\
\hline \multirow[t]{14}{*}{ H. albopunctatus group } & Hypsiboas albopunctatus & Rio Claro (SP) & 22 & $6 m+6 s m+10 s t$ & 44 & Centromeric & 8 & [4] \\
\hline & & Rio Claro (SP) & $22+1 B$ & $6 m+6 s m+10 s t+1 B$ & 45 & - & 8 & [4] \\
\hline & & - & 22 & - & - & - & - & [9] \\
\hline & & Pirenópolis (GO) & 22 & $10 m+4 s m+8 s m$ & 44 & - & - & [12] \\
\hline & & - & 22 & - & - & - & - & [14] \\
\hline & Hypsiboas lanciformis & Manaus (AM) & 22 & $8 m+6 s m+8 s t$ & 44 & Centromeric in most of chromosomes & 1,11 & Present study \\
\hline & & & & & & $\begin{array}{l}\text { Pericentromeric (pairs 1,3), short arm } \\
\quad \text { (pairs 4,11) and absent (pair 7) }\end{array}$ & & \\
\hline & Hypsiboas multifasciatus & Serranópolis (GO) & 24 & $14 m+8 s m+2 s t$ & 48 & - & - & [12] \\
\hline & & Iranduba (AM) & 24 & $10 m+6 s m+8 s t$ & 48 & $\begin{array}{l}\text { Interstitial in most of chromosomes and in } \\
\text { the long arms (pairs 11,12) }\end{array}$ & 11 & Present study \\
\hline & Hypsiboas raniceps & Brasilândia (MT) & 24 & $8 m+10 s m+6 s t$ & 48 & Almost absent & 11 & [4] \\
\hline & & - & 24 & - & - & - & - & [10] \\
\hline & & Tangará da Serra (MT) & 24 & $12 m+8 s m+4 s t$ & 48 & - & 1,11 & [11] \\
\hline & & - & 24 & - & - & - & - & [15] \\
\hline & & Iranduba (AM) & 24 & $10 m+6 s m+8 s t$ & 48 & Absent and pericentromeric (pair 5) & 11 & Present study \\
\hline \multirow[t]{17}{*}{ H. faber group } & Hypsiboas albomarginatus & Bertioga; (SP) & 24 & $18 m+6 s m$ & 48 & Centromeric & 2 & [6] \\
\hline & & Picinguaba (SP) & 24 & $18 m+6 s m$ & 48 & Centromeric & 2 & [6] \\
\hline & & - & 24 & - & - & - & - & [9] \\
\hline & & - & 24 & - & - & - & - & [16] \\
\hline & & Cariacica (ES) & 24 & $12 m+10 s m+2 s t$ & 48 & - & 2 & [17] \\
\hline & & Anchieta (ES) & 24 & $12 m+10 s m+2 s t$ & 48 & - & 2 & {$[17]$} \\
\hline & Hypsiboas crepitans & Piranhas (AL) & 24 & $8 m+4 s m+12 s t$ & 48 & Centromeric & 11 & [4] \\
\hline & & - & 24 & - & - & - & - & {$[8]$} \\
\hline & & - & 24 & - & - & - & - & [10] \\
\hline & & - & 24 & - & - & - & - & [14] \\
\hline & & - & 24 & $8 m+4 s m+10 s t$ & - & Telomeric & - & [18] \\
\hline & Hypsiboas faber & Mogi das Cruzes (SP) & 24 & $12 m+8 s m$ & 48 & - & 11 & [6] \\
\hline & & Biritiba-Mirim (SP) & 24 & $12 m+8 s m$ & 48 & - & 11 & [6] \\
\hline & & - & 24 & - & - & - & - & [9] \\
\hline & & Pedra Azul (ES) & 24 & $8 m+8 s m+8 s t$ & 48 & - & 11 & {$[17]$} \\
\hline & Hypsiboas lundii & Pirenópolis (GO) & 24 & $14 m+6 s m+4 s t$ & 48 & - & - & [12] \\
\hline & Hypsiboas pardalis & - & 24 & - & - & - & - & [14] \\
\hline
\end{tabular}


Table 1 Review of cytogenetic data available in the literature for Hypsiboas species (Continued)

\begin{tabular}{|c|c|c|c|c|c|c|c|c|}
\hline & & Cariacica (ES) & 24 & $10 m+10 s m+4 s t$ & 48 & - & 11 & [17] \\
\hline & Hypsiboas rosenbergi & - & 24 & - & - & - & - & [19] \\
\hline H. pellucens group & Hypsiboas rufitelus & - & 24 & - & - & - & - & [20] \\
\hline \multirow[t]{25}{*}{ H. pulchellus group } & Hypsiboas bischoffi & Rancho Queimado (SC) & 24 & - & - & - & 10 & [9] \\
\hline & & - & 24 & - & - & - & - & [21] \\
\hline & & - & 24 & - & - & - & - & [22] \\
\hline & Hypsiboas caingua & - & 24 & - & - & - & - & [23] \\
\hline & Hypsiboas cordobae & Cordoba (ARG) & 24 & $6 m+6 s m$ & 48 & Centromeric & & [24] \\
\hline & & San Luis (ARG) & 24 & $6 m+6 s m$ & 48 & Centromeric & & [24] \\
\hline & Hypsiboas guentheri & Rancho Queimado (SC) & 24 & - & - & - & 10 & [22] \\
\hline & Hypsiboas joaquini & - & 24 & - & - & - & - & [23] \\
\hline & Hypsiboas marginatus & São Francisco de Paula (RS) & 24 & $10 m+10 s m+4 s t$ & 48 & Centromeric & 10 & [25] \\
\hline & Hypsiboas polytaenius & - & 24 & - & - & - & - & [10] \\
\hline & & - & 24 & - & - & - & - & [15] \\
\hline & & - & 24 & - & - & - & - & [14] \\
\hline & & Santa Teresa (ES) & 24 & $12 m+10 s m+2 s t$ & 48 & & & [26] \\
\hline & Hypsiboas prasinus & - & 24 & - & - & - & - & [9] \\
\hline & & - & 24 & - & - & - & - & [23] \\
\hline & & Serra do Japi (SP) & 24 & $8 m+10 s m+6 s t$ & 48 & Centromeric & 9,12 & [27] \\
\hline & Hypsiboas pulchellus & - & 24 & - & - & - & - & [9] \\
\hline & & - & 24 & - & - & - & - & [14] \\
\hline & & - & 24 & - & - & - & - & [23] \\
\hline & & Cordoba (ARG) & 24 & $6 m+6 s m$ & 48 & Pericentromeric & & [24] \\
\hline & & - & 24 & - & - & - & - & [28] \\
\hline & Hypsiboas semiguttatus & - & 24 & - & - & - & - & [21] \\
\hline & & Camabará do Sul (SC) & 24 & $10 m+10 s m+4 s t$ & 48 & Centromeric & 1 & [25] \\
\hline & & São Francisco de Paula (RS) & 24 & $10 m+10 s m+4 s t$ & 48 & Centromeric & 1 & [25] \\
\hline & & Piraquara (PR) & 24 & $10 m+10 s m+4 s t$ & 48 & Centromeric & 1 & [25] \\
\hline \multirow[t]{4}{*}{ H. punctatus group } & Hypsiboas cinerascens & - & 24 & - & - & - & - & [14] \\
\hline & & Manaus (AM) & 24 & $6 m+12 s m+6 s t$ & 48 & $\begin{array}{l}\text { Centromeric (pairs 1,2,3,5,6,8) and poorly } \\
\text { distinguishable in most of the chromosomes }\end{array}$ & 11 & Present study \\
\hline & Hypsiboas punctatus & - & 24 & - & - & - & - & [14] \\
\hline & & - & 24 & - & - & - & - & [21] \\
\hline
\end{tabular}


Table 1 Review of cytogenetic data available in the literature for Hypsiboas species (Continued)

\begin{tabular}{|c|c|c|c|c|c|c|c|c|}
\hline & & - & 24 & - & - & - & - & [29] \\
\hline & & - & 24 & - & - & - & - & [30] \\
\hline \multirow[t]{7}{*}{ H. semilineatus group } & Hypsiboas boans & São Sebastião do Uatumã (AM) & 24 & $8 m+6 s m+10 s t$ & 48 & Centromeric and pericentromeric regions & 11 & Present study \\
\hline & Hypsiboas geographicus & - & 24 & - & - & - & - & [21] \\
\hline & & Santa Isabel do Rio Negro (AM) & 24 & $10 s m+6 s m+8 s t$ & 48 & $\begin{array}{l}\text { Centromeric and pericentromeric } \\
\text { regions, no distinguishable (pairs 6,7) }\end{array}$ & - & Present study \\
\hline & Hypsiboas gr. geographicus & - & 24 & - & - & - & - & [29] \\
\hline & Hypsiboas semilineatus & Santa Teresa (ES) & 24 & $10 m+6 s m+8 s t$ & 48 & - & 11 & [17] \\
\hline & Hypsiboas wavrini & Santa Isabel do Rio Negro (AM) & 24 & $10 m+6 s m+8 s t$ & 48 & Centromeric and pericentromeric regions & 11 & Present study \\
\hline & & São Sebastião do Uatumã (AM) & 24 & $10 m+6 s m+8 s t$ & 48 & Centromeric and pericentromeric regions & 11 & Present study \\
\hline
\end{tabular}


punctatus; and H. semilineatus $[13,17,31]$. This classification was suggested to reflect a number of distinct morphological characters among the species, principally coloration, size, the presence of interdigital membranes or spines on the prepollex of the males [32-34], and synapomorphies among their molecular markers [13]. According to a phylogeny proposal [13] for the consensus tree, all groups are considered monophyletic, and the $H$. punctatus group is a sister group separate from the other groups. H. pulchellus and $H$. faber are sister groups, as are $H$. pellucens and $H$. albopunctatus. The group $[H$. pulchellus $+H$. faber $]$ is a sister to $[H$. pellucens $+H$. albopunctatus], and these four species groups are a sister of $H$. semilineatus. Hypsiboas cinerascens (previously Hyla granosa in the Hyla granosa group) belongs to the Hypsiboas punctatus group (a monophyletic group fusion between the Hyla punctata and Hyla granosa groups) and $H$. wavrini is not included in the phylogeny because not all species are used to build a phylogenetic tree [13].

Regarding the karyotypic descriptions available for the species composing the $H$. albopunctatus group, there is some degree of confusion about the names adopted for the different taxa, resulting in divergences of the cytogenetic information available. Only $H$. albopunctatus, $H$. fasciatus, and $H$. raniceps have been karyotyped [4,9-11,15,31] even though reportedly there was no cytogenetic data available for $H$. fasciatus [31]. H. multifasciatus was cytogenetically described for the first time by Beçak [31]. However, Beçak [9] did not describe $H$. multifasciatus, but rather $H$. bischoffi, which belongs to the $H$. pulchellus group and is similar to $H$. multilineatus [34]. This indicates that the H. albopunctatus group may comprise species complexes [34], which would explain why different cytotypes have been described for the same species-such as $H$. multifasciatus from the states of Amazonas and Goiás in Brazil [12]. A similar situation was observed in $H$. raniceps, which has been described as having three distinct karyotypic formulas among the individuals encountered in the states of Mato Grosso and Goiás in central western Brazil [4,11], with one additional formula from Amazonas in northern Brazil.

There are both inter- and intraspecific variations in the chromosome formulas in the positions of their nucleolus organizer regions (NORs) and in the distribution of the constitutive heterochromatin [4,8,9,16-18,24,25,27]. Additionally, the species $H$. albopunctatus demonstrates a reduction in the diploid number, having $2 \mathrm{n}=22$ chromosomes in addition to the presence of a $\mathrm{B}$ chromosome $[4,12]$. The karyotypic patterns of organization are not established for the groups, and it is impossible to know if there are any cytogenetic features that characterize the Hypsiboas groups or if a concordance between the phylogenetic proposal and the chromosomal patterns exists. Thus, the objective of this study was to cytogenetically characterize one species of the $H$. punctatus group (H. cinerascens); three species of the $H$. semilineatus group ( $H$. boans, $H$. geographicus, and $H$. wavrini), and three species of the $H$. albopunctatus group ( $H$. lanciformis, $H$. multifasciatus, and $H$. raniceps) that occur in Amazonas, Brazil and to distinguish the Hypsiboas groups using chromosomal markers. In addition, we compared the results with Faivovich et al.'s phylogenetic proposal [13]. This manuscript is the first to describe $H$. lanciformis, $H$. boans, and $H$. wavrini, and we additionally characterize the diploid numbers for $H$. cinerascens, $H$. geographicus, $H$. multifasciatus, and $H$. raniceps.

\section{Results}

Diploid number, fundamental number and chromosomal formula

Hypsiboas lanciformis showed a diploid number of 22 (Figure 1a), while the species $H$. boans (Figure 1b), $H$. cinerascens (Figure 1c), H. geographicus (Figure 1d), H. multifasciatus (Figure 1e), H. raniceps (Figure 1f), and $H$. wavrini (Figure $1 \mathrm{~g}$ ) had $2 \mathrm{n}=24$ chromosomes, without any indication of sexual and/or supernumerary chromosomes. All of the species had a fundamental number (FN) of 48, with the exception of $H$. lanciformis $(\mathrm{FN}=44)$.

The chromosomal formulas were different for the four species: $H$. lanciformis, $8 \mathrm{~m}+6 \mathrm{sm}+8 \mathrm{st}$; $H$. boans, $8 \mathrm{~m}+6 \mathrm{sm}+10 \mathrm{st} ; H$. cinerascens, $6 \mathrm{~m}+12 \mathrm{sm}+6 \mathrm{st}$; and $H$. wavrini, $10 \mathrm{~m}+6 \mathrm{sm}+8 \mathrm{st}$. Three species, $H$. geographicus, $H$. multifasciatus, and $H$. raniceps had a chromosomal formula of $10 m+6 s m+8 s t$.

\section{C-banding and staining of the silver-binding nucleolar organizer region}

Different distribution patterns of constitutive heterochromatin were observed in the Hypsiboas species analyzed. Heterochromatin was distributed preferentially in the centromeric regions of most of the chromosomes of $H$. lanciformis, with some blocks invading the pericentromeric region, sometimes including the entire short arm, while other chromosomes showed no evident heterochromatin (Figure 2a). Large conspicuous blocks of constitutive heterochromatin in the centromeric and pericentromeric regions of all the chromosomes were present in $H$. boans (Figure 2b), H. geographicus (Figure 2d), and $H$. wavrini (Figure 2g), with the exception of the pairs 6 and 7 of the homologs of pairs 6 and 7 of $H$. geographicus, which did not show any heterochromatic blocks. The heterochromatic portions of $H$. cinerascens were poorly distinguishable (Figure 2c), although some pairs were clearly defined in the centromeric region as seen in pairs $1,2,3,5,6$, and 8 (Figure 2c). The C-banding in $H$. multifasciatus showed interstitial distributions along the short and 


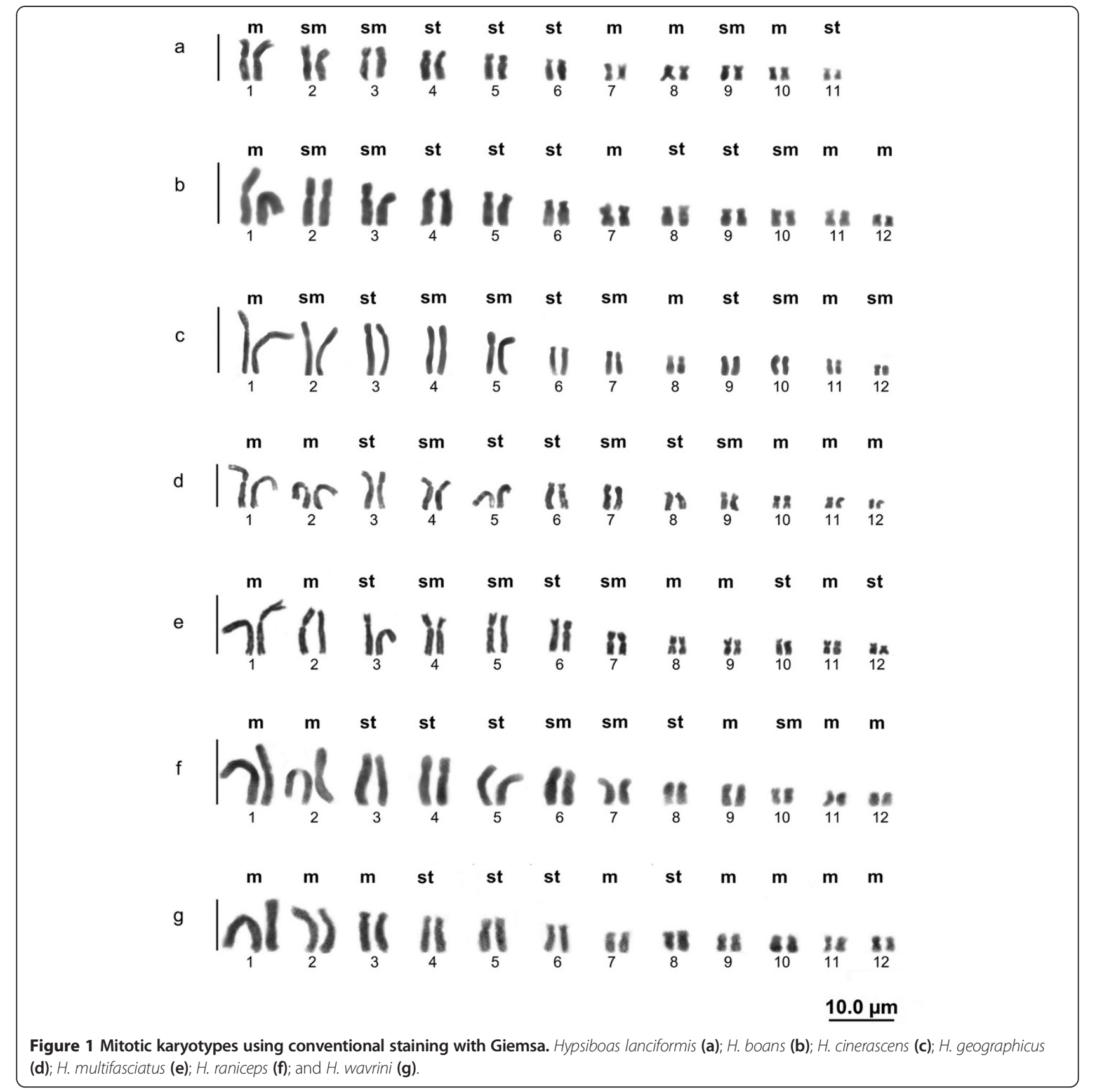

long arms of most of the chromosomes, as well as on the long arms of pairs 11 and 12 (Figure 2e). Constitutive heterochromatin was absent from most of the chromosomes of $H$. raniceps, although conspicuous heterochromatic blocks occurred in the pericentromeric regions of pair 5 (Figure 2f). In this study, the heterochromatin data of three species in the $H$. semilineatus group distinguished them from four species in the other groups (Figure 3).

Hypsiboas lanciformis had multiple NORs, with one centromeric mark in only one of the chromosomes of pair 1 and in the subterminal region of the long arm of pair 11 (box in Figure 2a). For the other species we investigated, a single chromosome pair was stained by the $\mathrm{AgNO}_{3}$. The silver-binding NORs were primarily located on chromosomal pair 11 in $H$. boans, $H$. cinerascens, $H$. multifasciatus, $H$. raniceps, and $H$. wavrini (boxes in Figures 2b, c, e-g) and on the centromeric region of pair 1 in $H$. geographicus (box in Figure 2d). Variations in the number of active sites were observed among and within individuals of all species.

\section{Telomeric sequence mapping}

Combining telomeric probes with fluorescence in situ hybridization (FISH) detected sites in the terminal 

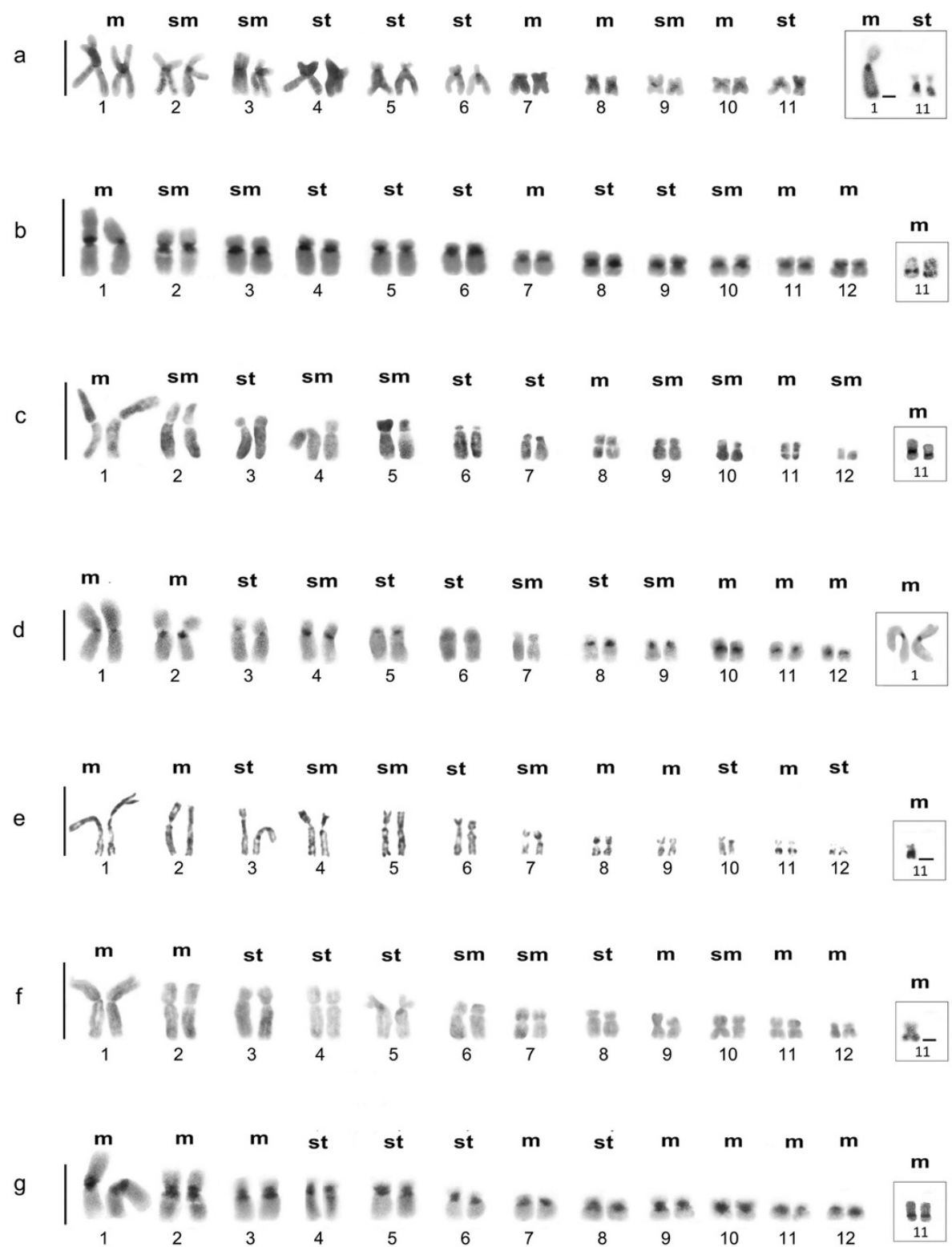

$10.0 \mu \mathrm{m}$

Figure 2 Distribution patterns of the constitutive heterochromatin. Hypsiboas lanciformis (a); H. boans (b); H. cinerascens (c); H. geographicus (d); H. multifasciatus (e); H. raniceps (f); and H. wavrini (g). The chromosome pairs bearing the nucleolus organizer regions are identified in the corresponding boxes.

regions of all of the chromosomes of all species. Interstitial telomeric sites (ITSs) were detected in three of the species belonging to the $H$. semilineatus group: $H$. boans, $H$. geographicus, and $H$. wavrini. In $H$. boans and $H$. wavrini (Figures $4 \mathrm{a}$ and c, respectively), the ITSs were seen on the short arms of both homologs of pair 2 and on the long arms of both homologs of pair 5 . The centromeric ITSs in $H$. geographicus were seen on both homologs of pairs 1 and 5; the ITSs on pair 1 correspond with the NOR sites in this species (Figure 4b). However,
ITSs were not found in $H$. cinerascens, $H$. lanciformis, $H$. multifasciatus and $H$. raniceps.

\section{Discussion}

The diploid chromosome number in the species of the family Hylidae varies between 18 and 30. Species of Dendropsophus have $2 \mathrm{n}=30$ chromosomes [3], those in Phyllomedusa have $2 \mathrm{n}=26$ chromosomes [35], Hyla have $2 \mathrm{n}=24$ chromosomes [36,37], Aplastodiscus has diploid numbers ranging from 18 to 24 [6], and most 


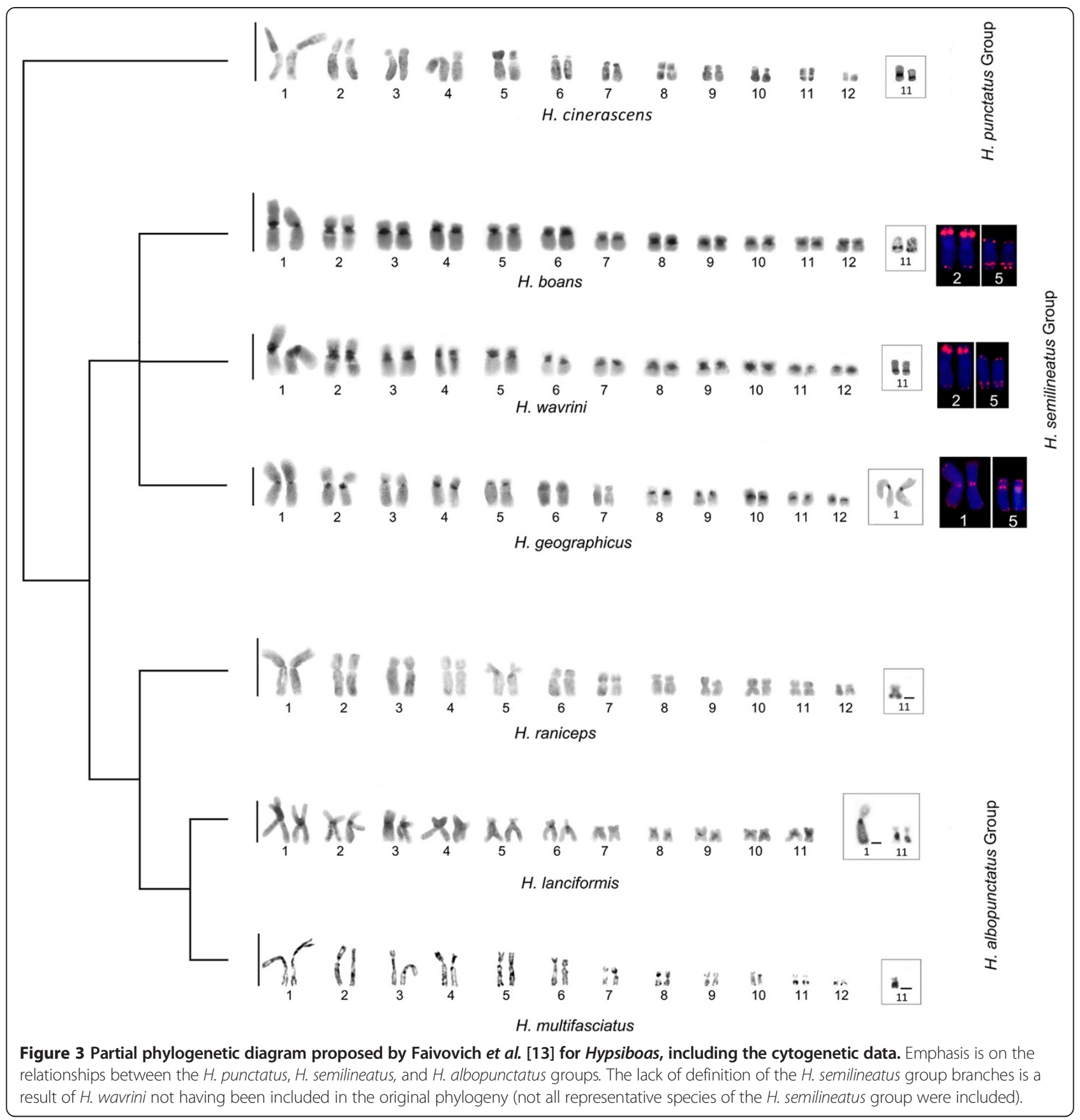

of the Hypsiboas species have $2 \mathrm{n}=24$ chromosomes $[10,18,28]$.

The diploid number of 22 can be seen in $H$. albopunctatus $[4,9]$ and $H$. lanciformis [present work], both of which are in the $H$. albopunctatus group. Based on the chromosome data of $H$. albopunctatus, it is possible that an end-to-end fusion occurred in the Hypsiboas ancestral $(2 \mathrm{n}=24)$ involving small chromosomes, probably chromosome pairs 11 (NOR region) and 12, because they are similar in length [4]. The same may also have occurred in $H$. lanciformis, explaining the evolution of the karyotype of this species with its reduced diploid number.

ITSs are repetitive sequences, which can derive from chromosomal rearrangements (centric fusion, in tandem fusion, or inversion) during vertebrate karyotype evolution $[38,39]$ representing the remaining sequences in newly formed chromosomes. Alternatively, ITSs can also result from the amplification of telomeric sequences, be the result of unequal crossing-over and transposition, be sequences introduced by a telomerase error, or be the result of integration between transposons and telomeric 


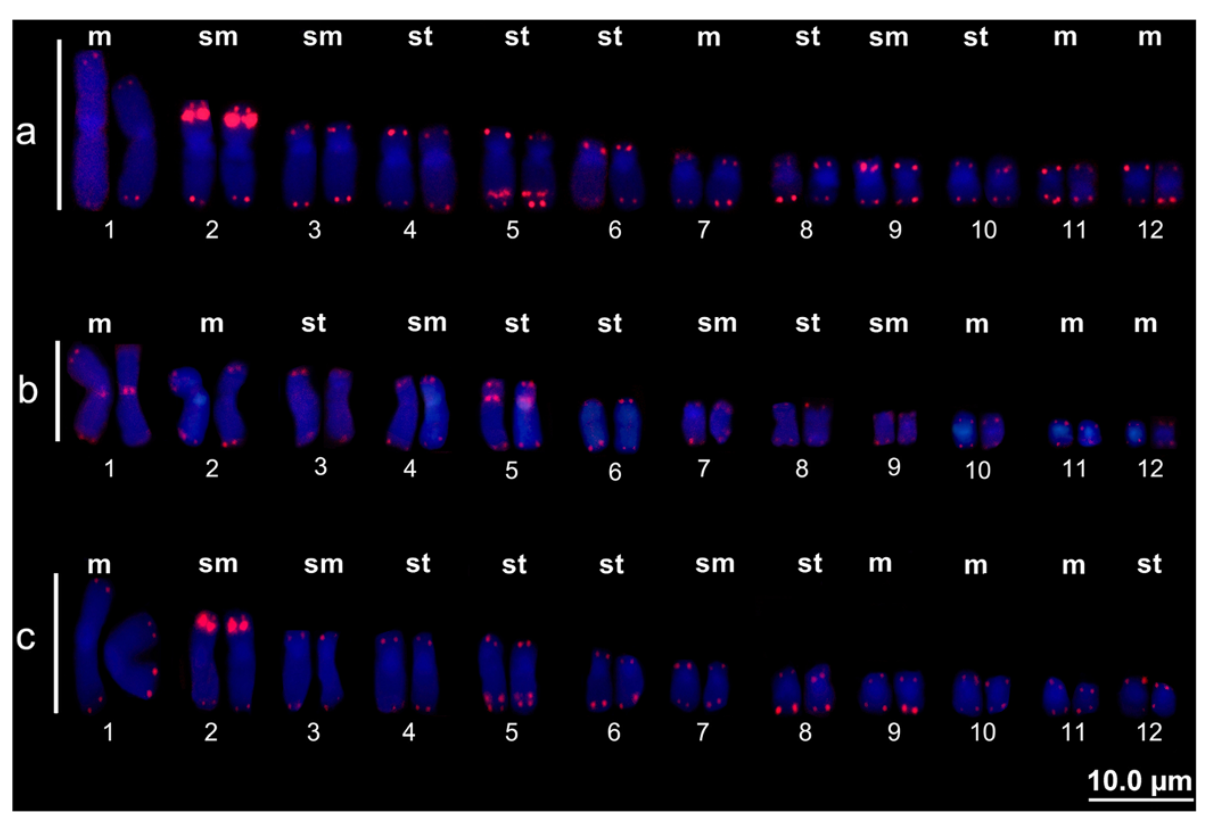

Figure 4 Telomeric hybridization. Hypsiboas boans (a), H. geographicus (b), and H. wavrini (c), which are in the H. semilineatus group, showed signs of hybridization based on the telomeric probe (red). The chromosomes were counterstained with DAPI.

sequences $[37,38]$. ITSs have been found in hylid frogs and in some species of Hyla in North America such as $H$. chrysoscelis and $H$. versicolor; these have been attributed to unequal crossing-over during meiosis, submicroscopic deletions, and differential amplifications $[37,40]$. Telomeric sequences commonly occur outside of the terminal regions in the Hylidae family $[37,38]$ and are present in $H$. boans, $H$. geographicus, and $H$. wavrini belong to $H$. semilineatus group. These sequences may be the result of chromosomal rearrangements and represent the remains of sequences in newly formed chromosomes, or they may be due to integration between transposons and telomeric sequences as has been observed in other species $[37,38]$. There is no consensus on the presence or absence of ITSs and their relation to chromosomal rearrangements, because many factors may be involved [41]. However, no ITSs were found in the other four Hypsiboas species analyzed in this study, suggesting the answer may be selection by an unknown agent that may not alter their fitness [37].

The absence of the ITSs in most Hypsiboas species does not necessarily indicate that the hypothesis that Hypsiboas species were derived from a common ancestor with 26 chromosomes is incorrect. Chromosomes derived from fusion events may have small telomeric sites that cannot be easily detected by FISH, or the telomeres could be lost before the fusion or eroded by molecular processes [42]. As there has been no alteration in the basal diploid number of Hypsiboas, the ITSs observed in the chromosomes of $H$. boans, $H$. geographicus, and $H$. wavrini probably reflect non-Robertsonian rearrangements, given that that these three species are not found in the basal group.

Hypsiboas cinerascens (previously Hyla granosa within the Hyla granosa group) belongs to the Hypsiboas punctatus group (monophyletic group fusion between the Hyla punctata and Hyla granosa groups) [13] and displays the basal cytogenetic characteristics of the Hypsiboas, including a diploid number of 24, poorly visible constitutive heterochromatin, and an active NOR on a single chromosome pair [14, present work]. A detailed comparison between the karyotypic patterns of the Hypsiboas punctatus group was not possible, because the data was restricted to the Hypsiboas punctatus diploid number of 24 [14,21,29,30].

The species $H$. boans, $H$. geographicus, and $H$. wavrini ( $H$. semilineatus group) show processes of heterochromatin accumulation or heterochromatization [43-45] during their evolution, a characteristic that distinguishes these species from the others in the group. Additionally, $H$. boans and $H$. wavrini are phylogenetically related, with similar patterns of constitutive heterochromatin distribution, and the number and localization of the NORs and ITSs. The proximity between $H$. wavrini and $H$. boans can also be seen in their morphological and reproductive similarities, which makes it difficult to differentiate between these species in the field $[46,47]$. Both species have been found in sympatry in Colombia, and though they occupy identical niches, they differ in their vocalization and reproductive periods [48]. However, the karyotype 
formulas differ between $H$. boans and $H$. wavrini, allowing them to be differentiated [present work].

Almost $90 \%$ of speciation events are accompanied by chromosome changes [42]. NORs are considered excellent markers in karyotype evolution studies in amphibians [49,50], despite the occurrence of rare variations within the species [51]. Most anuran genera have heteromorphic NORs, and the differences in their size may be due to in tandem duplication or triplication, which can affect one or both DNAr clusters [49]. The duplicated NORs found in $H$. albomarginatus may have resulted from differential gene activity or be a duplication by mobile elements [47]. In one study, three of four species ( $H$. albomarginatus, $H$. semilineatus, and H. pardalis) had heteromorphic NORs [17].

Hypsiboas geographicus (H. semilineatus group) had NORs present on the centromeric region of pair 1, while in the other species of this group, the NORs were present in another chromosomes pair, such as pair 11 in $H$. semilineatus [17]. In $H$. geographicus, the NOR is in same region as the ITS, and it is possible that both structures are associated with different satellite/repetitive DNA classes, because they are in the centromeric region [52]. Despite some authors being unable to find an association between the NORs (specifically $18 \mathrm{~S}$ rDNA) and ITSs [37], this would explain the amplification of those telomeric sequences in the interstitial region of the chromosomes. However, the silver nitrate impregnation technique only identifies active sites [53], meaning the possibility of multiple ribosomal sites in these groups or variable chromosomal localization among the species cannot be eliminated. Multiple NOR active sites were observed in $H$. lanciformis [present work] and $H$. raniceps [4] (both in the $H$. albopunctatus group) [13], as well as in $H$. prasinus (H. pulchellus group) [9,23,27]. The hybridization of $45 \mathrm{~S}$ ribosomal DNA probes only in $H$. albopunctatus and $H$. pardalis indicated the presence of one labeled chromosome pair $[14,17]$. Since silver associates with nucleolar proteins involved in the transcriptional activity of ribosomal genes from the 45S rDNA cistrons [51,52] and can also impregnate heterochromatic regions rich in acidic residues [54], the multiple NORs present in $H$. lanciformis and $H$. raniceps may be indicating a heterochromatic region. However, the position of the NORs varies among the species, and it is possible that the ribosomal genes are changing during the karyotypic evolutionary process $[17,48,49]$. Despite some authors [17] finding that each monophyletic clade in the Hylidae phylogenetic tree [13] had the ribosomal cistron located in a specific chromosome pair (based on the NOR data), there may be no typical pattern for each group, with the presence of both simple and multiple NORs among the species of those taxa (Table 1).
In addition to the differences in the number and localization of the NORs, two different diploid numbers and different karyotypic formulas were seen in the $H$. albopunctatus group. As such, in spite of the fact that $H$. albopunctatus has $2 \mathrm{n}=22$ chromosomes, other species of the group have a diploid number of $24[4,9,10,12,15]$, and this reduction to 22 is not a true characteristic of the group. In addition, despite the decrease to $2 n=22$ chromosomes in H. lanciformis, no ITSs were encountered in that species, possibly due to genetic erosion of those sequences. Given that $H$. lanciformis is typically found in forest fragments and along forest edges [55-57] where it would be more susceptible to anthropogenic interactions such as water contamination, which can cause several diseases [58], the lack of ITSs could also be due to selection by an unknown agent that does not prejudice the development of the species [37,41]. These same forces may also be acting on $H$. albopunctatus, which frequently occurs in disturbed areas [57]; in addition to having 22 chromosome pairs, many individuals of this species have supernumerary chromosomes [4].

Both species, Hypsiboas lanciformis [present work] and H. albopunctatus [4,9], had a reduced chromosome number $(2 n=22)$ relative to their co-generic species $(2 n=24)$ in a phylogenetic tree of the family Hylidae [13]. However, looking at the diploid number data plotted for this tree, it is apparent that chromosome number can either occur independently in these species, is related to their natural history, or is a species characteristic [43]. Thus, they have the same common ancestor, but are grouped in different clades [13].

Different patterns of distribution of the heterochromatin were found in the $H$. albopunctatus group. $H$. lanciformis had heterochromatic blocks in the centromeric region of most of its chromosomes [present work], as did $H$. albopunctatus [4,12]. H. raniceps and $H$. multifasciatus showed weak heterochromatic blocks distributed in only a few pairs of chromosomes. In addition, there were clear differences in the distribution patterns of heterochromatin among the populations of $H$. raniceps such as between the individuals from the northern and central regions of Brazil $[4,10,11,15]$. The variation in the quantity and distribution of the constitutive heterochromatin is an important characteristic that can be used to differentiate between populations based on an epigenetic mechanism [59]. Additionally, heterochromatin is normally rich in repetitive sequences that may have important roles in speciation and/or adaptation, as they are less subject to selective pressurewhich favors the accumulation of differences during evolutive processes $[44,60,61]$.

Differences in genome size are primarily due to events of heterochromatin addition or deletion involving DNA satellite families [62]. The DNA content was $6.61 \mathrm{pg} / \mathrm{N}$ for $H$. lanciformis, while those of $H$. cinerascens (synonym of Hyla granosa) and Hypsiboas geographicus were $4.53 \mathrm{pg} / \mathrm{N}$ 
and $3.28 \mathrm{pg} / \mathrm{N}$ [45], respectively. Heterochromatin was present in the centromeric region in most of the chromosomes of both $H$. lanciformis and $H$. cinerascens, but like the DNA content, the quantity of heterochromatin was different relative to others such as $H$. lanciformis, which had more heterochromatic blocks and a higher DNA content. However, when the C-banding patterns of $H$. lanciformis and $H$. geographicus were compared, their heterochromatin was similar, despite the difference in their DNA content. Recent work has demonstrated epigenetic influences on the pattern of heterochromatin distribution in chromosomes $[59,63]$ that could explain the absence of a correlation between the high DNA content and more heterochromatic blocks found in $H$. geographicus and the number and localization of NORs and ITSs.

\section{Conclusion}

The data presented in this study reinforces the complexity previously observed within the genus Hypsiboas and in the different groups that compose this taxon. More studies focusing on this group and covering larger sampling areas, especially in the Brazilian Amazon, are needed to gain a better understanding of this fascinating, but complex group.

\section{Methods}

\section{Species and collection localities}

The collections were undertaken between June 2011 and June 2012, during both the rainy and dry seasons under the authorization of the Instituto Chico Mendes de Conservação da Biodiversidade (11323-0). This work was authorized by the Ethics Committee of Animal Experimentation (CEEA) of the Amazonas Federal University (no. 075/2012). Voucher specimens were deposited in the Paulo Bührnheim Zoological Collection of the Amazonas Federal University (CZPB/UFAM) and the Collection of Amphibians and Reptiles of the National Institute of Amazonian Research (INPA-H).

Twenty-two specimens were analyzed: 1 male $H$. boans (INPA-H 314433), collected in São Sebastião do Uatumã (AM) $\left(0^{\circ} 50^{\prime}\right.$ to $1^{\circ} 55^{\prime} \mathrm{S} ; 58^{\circ} 50^{\prime}$ to $\left.60^{\circ} 10^{\prime} \mathrm{W}\right)$; 4 male $H$. cinerascens (CZPB/UFAM 153/315, CZPB/UFAM $154 / 316-318)$, collected in Manaus (AM) (0304'34"S; $\left.59^{\circ} 57^{\prime} 30^{\prime \prime W}\right) ; 1$ female and 3 male $H$. geographicus (INPA-H 31445, INPA-H 31447-31448, INPA-H 31450), collected in Santa Isabel do Rio Negro (AM) $\left(0^{\circ} 24 ' 24^{\prime \prime N}\right.$; 651'1"W); 3 male $H$. lanciformis (CZPB/UFAM 155/319, CZPB/UFAM 159/331,CZPB/UFAM 159/333), collected in Manaus (AM) $\left(03^{\circ} 04^{\prime} 34^{\prime \prime S}\right.$; 59 57'30"W); 1 female $H$. multifasciatus (CZPB/UFAM 156/320), collected in Iranduba (AM) (0309'47"S; 59 54'29"W); 2 female and 4 male $H$. raniceps (CZPB/UFAM 158/324-329), collected in Iranduba (AM) $\left(03^{\circ} 09^{\prime} 47^{\prime \prime S} ; 59^{\circ} 54^{\prime} 29^{\prime \prime W}\right) ; 1$ female $H$. wavrini, collected in São Sebastião do Uatumã (AM) $\left(0^{\circ} 50^{\prime}\right.$ to $1^{\circ} 55^{\prime} \mathrm{S}$; $58^{\circ} 50^{\prime}$ to $\left.60^{\circ} 10^{\prime} \mathrm{W}\right)$, and 2 male $H$. wavrini
(INPA-H 31441-31442; INPA-H 31444), collected in Santa Isabel do Rio Negro (AM) (0²4'24"N; 65'1' $\left.1^{\circ} \mathrm{W}\right)$.

\section{Chromosomal analyses}

Mitotic chromosomes were obtained from the bone marrow and liver of the hylids after in vitro (1\%) and in vivo $(0.1 \%)$ colchicine exposure $[64,65]$. Cell division was induced in some specimens by injecting them with biological yeast $(0.1 \mathrm{~mL}$ per $10 \mathrm{~g}$ of animal bodyweight) and maintaining them alive for 48-72 $\mathrm{h}[35,66]$.

\section{Classical and molecular cytogenetic analysis}

The cell suspensions were analyzed after routine staining with conventional stain (10\%), C-banding [54], Ag-NOR staining [53], and FISH [67] with a telomeric probe. The FISH telomeric probe was digoxigenin-labelled by a nick translation reaction using a Roche $^{\mathrm{TM}}$ kit and amplified by polymerase chain reactions as previously described [68]. Chromosomes were organized by decreasing size, and the morphology was determined based on the centromere position [69]. Fundamental numbers were determined by conventional staining at metaphase and by exposure to barium hydroxide.

\section{Abbreviations}

FISH: Fluorescence in situ hybridization; ITS: Interstitial telomeric site; NOR: Nucleolar organizer region.

\section{Competing interests}

The authors declare that they have no competing interests.

\section{Authors' contributions}

TLM, ACC, CHS, and DOCT collected the samples and analyzed the results. TLM and ACC collaborated on all genetic procedures, undertook the bibliographic review, and coordinated the writing of the paper. CHS participated in developing the molecular cytogenetics techniques with TLM and analyzing the results. MCG and MM coordinated the study, participated in its design, analyzed the results, and revised the manuscript. All authors read and approved the final manuscript.

\section{Acknowledgements}

We thank Alexandre Almeida and Karla da Silva for helping in the zoological collection from INPA and UFAM, the herpetology group for the collection and identification of some Hypsiboas specimens, and the cytogenetic group (both from the SISBIOTA project) and Dra. Eliana Feldberg for using epifluorescence microscope. Financial support was provided by Fundação de Amparo à Pesquisa do Estado do Amazonas (FAPEAM; Citogenômica comparativa de anuros amazônicos-Universal Amazonas Edital 021/2011) and Conselho Nacional de Desenvolvimento Científico e Tecnológico (CNPq; 573976/2008-2, 558318/2009-6, 563348/2010-0). This study was supported by a graduate fellowship from Coordenação de Aperfeiçoamento de Pessoal de Nível Superior to TLM and Research Productivity grants from CNPq to MM and FAPEAM to MCG.

\section{Author details}

${ }^{1}$ Instituto Nacional de Pesquisas da Amazônia, Programa de Pós-Graduação em Genética, Conservação e Biologia Evolutiva, Av. André Araújo, 2936, 69080-971 Manaus, AM, Brazil. 'Universidade Federal do Amazonas, Instituto de Ciências Biológicas, Departamento de Biologia, Laboratório de Citogenômica, Av. General Rodrigo Octávio Jordão Ramos, 3000, 69077-000 Manaus, AM, Brazil. Universidade Federal do Amazonas, Instituto de Ciências Biológicas, Programa de Pós-Graduação em Diversidade Biológica, Av. General Rodrigo Octávio Jordão Ramos, 3000, 69077-000 Manaus, AM, Brazil. 
Received: 27 October 2013 Accepted: 24 March 2014

Published: 4 April 2014

\section{References}

1. Frost DR: Amphibian species of the world 6.0: an online reference. [http://research.amnh.org/herpetology/amphibia/index.html] Accessed on February 1, 2014

2. Avila-Pires TC, Hoogmoed MS, Vitt LJ: Herpetofauna da Amazônia. In Herpetologia do Brasil II. Edited by Nascimento LB, Oliveira ME. Belo Horizonte: Sociedade Brasileira de Herpetologia; 2007:13-43.

3. Medeiros LR, Rossa-Feres DC, Recco-Pimentel SM: Chromosomal differentiation of Hyla nana and Hyla sanborni (Anura, Hylidae), with description of NOR polymorphism in H. nana. J Hered 2003, 94:149-154.

4. Gruber SL, Haddad CFB, Kasahara S: Chromosome banding in three species of Hypsiboas (Hylidae, Hylinae), with special reference to a new case of $B$-chromosome in anuran frogs and to the reduction of the diploid number of $2 n=24$ to $2 n=22$ in the genus. Genetica 2007, 130:281-291.

5. Ferro JM, Marti DA, Bidau CJ, Suarez P, Nagamachi C, Pieczarka J, Baldo D: B chromosomes in the tree frog Hypsiboas albopunctatus (Anura: Hylidae). Herpetologica 2012, 68:482-490.

6. Carvalho KA, Garcia PCA, Recco-Pimentel SM: Cytogenetic comparison of tree frogs of the genus Aplastodiscus and the Hypsiboas faber group (Anura, Hylidae). Genet Mol Res 2009, 8:1498-1508.

7. Duellman WE, Trueb L: Biology of amphibians. New York: McGraw-Hill; 1986

8. Duellman WE, Cole CJ: Studies of chromosomes of some anuran amphibians (Hylidae and Centrolenidae). Syst Biol 1965, 14:139-143.

9. Beçak ML: Chromosomal analysis of eighteen species of Anura. Caryologia 1968, 21:191-208.

10. Rabelo MN: Chromosome studies in Brazilian anurans. Caryologia 1970, 23:45-59.

11. Carvalho FK, Fernandes A, Barth A, Custódio RJ: Tempo ou antropismo como fatores causadores de alterações cromossômicas para uma população de Hypsiboas raniceps (Anura: Hylidae) (Cope, 1862). In IV Congresso de Iniciação Científica:23-24 October 2008. Edited by UNEMAT. Cárceres; 2008:1-4.

12. de Oliveira HHP, Souza CCN, Ribeiro CL, da Cruz AD, Bastos RP, Melo e Silva D: Citogenética comparativa das famílias Leptodactylidae e Hylidae do cerrado goiano. Estudos 2010, 37:725-735.

13. Faivovich J, Haddad CFB, Garcia PCA, Frost DR, Campbell JA, Wheeler WC: Systematic review of the frog family Hylidae, with special reference to Hylinae: phylogenetic analysis and taxonomic revision. Bull Am Mus Nat Hist 2005, 294:1-240.

14. Bogart JP: Evolution of anurans karyotypes. In Evolutionary Biology of the Anurans. Edited by Vial JL. Columbia: University of Missouri Press; 1973:337-349.

15. Rabelo MN, Beçak ML, Beçak W: Contribuição à citotaxonomia da família Hylidae. Arq Museu Nac 1971, 54:285-286.

16. Gruber SL: Estudos citogenéticos em espécies do gênero Hyla (Anura, Hylidae) dos grupos com $2 n=24$ e $2 n=30$, com técnicas de coloração diferencial. Master thesis 2002. Universidade Estadual Paulista, Departamento de Biologia.

17. Nunes RRA, Fagundes V: Patterns of ribosomal DNA distribution in hylids frogs from Hypsiboas faber and $\mathrm{H}$. semilineatus species groups. Gen Mol Biol 2008, 31:982-987.

18. Nunes RRA: Citogenética de anfíbios da família Hylidae do Espírito Santo. Master thesis 2006. Universidade Federal do Espírito Santo, Departamento de Biologia.

19. León PE: Report of the chromosome numbers of some Costa Rica anurans. Rev Biol Trop 1970, 17:119-124.

20. Duellman WE: Additional studies of chromosomes of anuran amphibians. Syst Zool 1967, 16:38-43.

21. Foresti F: Aspectos cromossômicos da família Hylidae (Amphibia-Anura) Master thesis 1972. Universidade de São Paulo, Departamento de Biologia.

22. Raber SC, Carvalho KA, Garcia PCA, Vinciprova G, Recco-Pimentel SM: Chromosomal characterization of Hyla bischoffi and Hyla guentheri (Anura, Hylidae). Phyllomedusa 2000, 3:43-49.

23. Ananias F: Caracterização cromossômica de espécies e subespécies do grupo H. pulchella (Amphibia, Anura, Hylidae). Master thesis 1996. Universidade Estadual de Campinas, Departamento de Biologia.

24. Baraquet M, Salas NE, Martino AL: C-banding pattern and meiotic behavior in Hypsiboas pulchellus and H. cordobae (Anura, Hylidae). J Basic Appl Genet 2013, 24:32-39.
25. Ananias F, Garcia PCA, Recco-Pimentel SM: Conserved karyotypes in the Hyla pulchella species group (Anura, Hylidae). Hereditas 2004 40:42-48.

26. Nunes RRA, Fagundes V: Cariótipo de oito espécies de anfíbios das subfamílias Hylinae e Phyllomedusinae (Anura, Hylidae) do Espírito Santo, Brasil. Bol Mus Biol Mello Leitão 2008, 23:21-26.

27. Baldissera Junior FA, Oliveira PSL, Kasahara S: Cytogenetics of four Brazilian Hyla species (Amphibia-Anura) and description of a case with a supernumerary chromosome. Rev Bras Genét 1993, 16:335-345.

28. Saez FA, Brum N: Chromosomes of South American amphibians. Nature 1960, 185:945

29. Bogart JP, Bogart JE: Genetic compatibility experiments between some South American anuran amphibians. Herpetologica 1971, 27:229-235.

30. Anderson K: Chromosome evolution in holoarctic Hyla treefrogs. In Amphibian Cytogenetics and Evolution. Edited by Green DM, Sessions SK. San Diego: Academic Press; 1991:299-331.

31. Catroli GF, Kasahara S: Cytogenetic data on species of the family Hylidae (Amphibia, Anura): results and perspectives. Publicação UEPG Ciênc Biol Saúde 2009, 15:67-86.

32. Cochran DM: Frogs of southeastern Brazil. Bull U S Nat Mus 1955, 206:1-423.

33. De Sá RO: Hyla multifasciata. Catalogue of American Amphibians and Reptiles 1996, 624:1-4.

34. Gruber SL, Haddad CFB, Kasahara S: Evaluating the karyotypic diversity in species of Hyla (Anura; Hylidae) with $2 \mathrm{n}=30$ chromosomes based on the analysis of ten species. Folia Biol 2005, 51:68-75.

35. Paiva CR, Nascimento J, Silva APZ, Bernarde OS, Ananias F: Karyotypes and Ag-NORs in Phyllomedusa camba De La Riva, 1999 and P. rhodei Mertens, 1926 (Anura, Hylidae, Phyllomedusinae): cytotaxonomic considerations. Ital J Zool 2010, 77:116-121.

36. Wiley JE: Chromosome banding patterns of treefrogs (Hylidae) of eastern United States. Herpetologica 1982, 38:507-520

37. Wiley JE, Meyne J, Little MN, Stout JC: Interstitial hybridization sites of the (TTAGGG) telomeric sequence on the chromosomes of some North American hylid frogs. Cytogenet Cell Genet 1992, 51:55-57.

38. Meyne J, Baker RJ, Hobart HH, Hsu TC, Ryder OA, Ward OG, Wiley JE, Wurster-Hill DH, Yates TL, Moyziz RK: Distribution of non-telomeric sites of the (TTAGGG) telomeric sequence in vertebrate chromosomes. Chromosoma 1990, 99:3-10.

39. Andrades-Miranda J, Zanchin NIT, Oliveira LFB, Langguth AR, Mattevi MS: $\left(\mathrm{T}_{2} \mathrm{AG}_{3}\right)$ n telomeric sequence hybridization indicating centric fusion rearrangements in karyotype of the rodent Oryzomys subflavus. Genetica 2002, 144:11-16.

40. Wiley JE, Little ML, Romano MA, Blount DA, Cline GR: Polymorphism in the location of the $18 \mathrm{~S}$ and $28 \mathrm{~S}$ rRNA genes on the chromosomes of the diploid-tetraploid treefrogs Hyla chrysoscelis and Hyla versicolor. Chromosoma 1989, 97:481-487.

41. Silva MJJ: Estudos dos processos de diferenciação cariotípica, baseados em citogenética convencional e molecular, em quatro gêneros de roedores brasileiros. PhD thesis 1999. Universidade de São Paulo, Departamento de Biologia.

42. Mandrioli M, Cuoghi B, Marini M, Mancardi GC: Localization of the (TTAGGG) telomeric repeat in the chromosomes of the pufferfish Tetraodon fluviatilis (Hamilton Buchanan) (Osteichthyes). Caryologia 1999, 52:155-157.

43. Prado CPA, Haddad CFB, Zamudio KR: Cryptic lineages and Pleistocene population expansion in a Brazilian Cerrado frog. Mol Ecol 2012, 21:921-941.

44. Bohne A, Brunet F, Galiana-Arnoux D, Schulthesis C, Volff JN: Transposable elements as drivers of genomic and biological diversity in vertebrates. Chromosome Res 2008, 16:203-215.

45. Gregory TR: Animal Genome Size Data Base. [http://www.genomesize. com] Accessed on February 24, 2014.

46. Hoogmoed MS: Resurrection of Hyla wavrini Parker (Amphibia: Anura: Hylidae), a gladiator frog from northern South America. Zool Mededelingen 1990, 64:71-93.

47. Martins M, Moreira G: The nest and the tadpole of Hyla wavrini, Parker (Amphibia, Anura). Mem Inst Butantan 1991, 53:197-204.

48. Lynch JD, Suárez-Mayorga AM: The distribution of the gladiator frogs (Hyla boans group) in Colombia, with comments on size variation and sympatry. Caldasia 2001, 23:491-507.

49. Lourenço LB, Recco-Pimentel SM, Cardoso AJ: Polymorphism of the nucleolus organizer regions (NORs) in Physalaemus petersi (Amphibia, Anura, Leptodactylidae) detected by silver staining and fluorescence in situ hybridization. Chromosome Res 1998, 6:621-628. 
50. Schmid M: Chromosome banding in Amphibia I: Constitutive heterochromatin and nucleolus organizer regions in Bufo and Hyla. Chromosoma 1978, 66:361-388.

51. Schmid M: Chromosome banding in Amphibia VII: Analysis of the structure and variability of NORs in Anura. Chromosoma 1982, 87:327-344.

52. Boisvert FM, Koningsbruggen SV, Navascués J, Lamons AL: The multifunctional nucleolus. Nat Rev Mol Cell Biol 2007, 8:574-585.

53. Howell WM, Black DA: Controlled silver-staining of nucleolus organizer regions with a protective colloidal developer: a 1- step method. Experientia 1980, 36:1014-1015.

54. Sumner AT: A simple technique for demonstrating centromeric heterochromatin. Exp Cell Res 1972, 74:304-306.

55. Lima AP, Magnusson WE, Menin M, Erdtmann LK, Rodrigues DJ, Keller C, Hödl W: Guia de sapos da Reserva Adolpho Ducke, Amazônia Central (Guide to the frogs of Reserva Adolpho Ducke, Central Amazonia). Instituto Nacional de Pesquisas da Amazônia: Manaus; 2012.

56. Menin M, Waldez F, Lima AP: Temporal variation in the abundance and number of species of frogs in 10,000 ha of a forest in central Amazonia, Brazil. J Herpetol 2008, 3:68-81.

57. Tovar-Rodríguez WT, Chacón-Ortiz A, Durán RDJ: Abundancia, disposición espacial e historia natural de Hypsiboas lanciformis (Anura: Hylidae) al suroeste de los Andes Venezuelanos. Rev Acad Colomb Cienc 2009, 127:193-200.

58. Mylniczenko N: Amphibians. In Manual of Exotic Pet Practice. Edited by Tully TNJ. Saint Louis: Saunders Elsevier; 2009:73-111.

59. Probst AV, Almouzni G: Heterochromatin establishment in the context of genome-wide epigenetic reprogramming. Trends Genet 2011, 27:177-185.

60. Moraes S, Knoll-Gellida A, André M, Barthe C, Babin PJ: Conserved expression of alternative splicing variants of peroxisomal acyl-CoA oxidase I in vertebrates and developmental and nutritional regulation in fish. Physiol Genomics 2007, 28:239-252.

61. Martins C: Chromosomes and repetitive DNAs: a contribution to the knowledge of the fish genome. In Fish Cytogenetics. Edited by Pisano E, Ozouf-Costaz C, Foresti F, Kapoor BG. Enfield: Science Publishers; 2007:421-453.

62. Bosco G, Campbell P, Leiva-Neto JT, Markow TA: Analysis of Drosophila species genome size and satellite DNA content reveals significant differences among strains as well as between species. Genetics 2007, 177:1277-1290.

63. Elgin SC, Grewal SI: Heterochromatin: silence is golden. Curr Biol 2003, 13:895-898

64. Ford C, Hamerton J: A colchicine hypotonic citrate squash sequence for mammalian chromosomes. Stain Technol 1956, 31:247-251.

65. Kasahara S: Introdução à pesquisa em citogenética de vertebrados. Sociedade Brasileira de Genética: Ribeirão Preto; 2009.

66. Oliveira C: Estudos citogenéticos no gênero Corydoras (Pisces, Siluriformes, Callichthyidae). Master thesis 1987. Universidade de São Paulo, Departamento de Biologia.

67. Pinkel D, Straume T, Gray JW: Cytogenetic analysis using quantitative, high sensitivity, fluorescence hybridization. Proc Natl Acad Sci U S A 1986, 83:2934-2938.

68. Ijdo JW, Wells RA, Baldini A, Reeders ST: Improved telomere detection using a telomere repeat probe $(T T A G G G)_{n}$ generated by PCR. Nucleic Acids Res 1991, 19:4780.

69. Green D, Sessions SK: Nomenclature for chromosomes. In Amphibian Cytogenetics and Evolution. San Diego: Academic Press; 1991.

doi:10.1186/1471-2156-15-43

Cite this article as: Mattos et al: Karyotypic diversity in seven Amazonian anurans in the genus Hypsiboas (family Hylidae). BMC Genetics 2014 15:43.

\section{Submit your next manuscript to BioMed Central and take full advantage of:}

- Convenient online submission

- Thorough peer review

- No space constraints or color figure charges

- Immediate publication on acceptance

- Inclusion in PubMed, CAS, Scopus and Google Scholar

- Research which is freely available for redistribution

Submit your manuscript at www.biomedcentral.com/submit
Ciomed Central 